\title{
GOMMENT
}

\section{COMMITMENT TO FARVIEW: INCOMPETENCY TO STAND TRIAL IN PENNSYLVANIA}

\section{Antitherapeutic Value of Farview}

The Commonwealth of Pennsylvania has maintained Farview State Hospital as an institution devoted exclusively to the care of patients afflicted with mental problems who either endanger the security of other state hospitals or stand charged or convicted of a crime. ${ }^{1}$ However, there are several factors which prevent the Farview staff from providing effective or adequate care for patients committed there. First, Farview is hopelessly overcrowded and understaffed. Although the optimum population is 999, Farview as of February 7, 1969, housed 1,167 patients. $^{2}$ These patients received care from a staff comprising one accredited psychiatrist, six physicians, five psychologists, five Registered Nurses, twelve licensed Practical Nurses, two social workers with Masters degrees, one case worker with a Bachelors degree, one who has no degree, and one recreational therapist, but no occupational therapists who have met the state civil service requirements. ${ }^{3}$ Located in a remote and sparsely populated area of Pennsylvania about 200 miles from Philadelphia and paying sub-standard state salaries, it has difficulty in attracting enough competent professionals to its staff. Limited in resources, it can provide no more than "milieu" 4 and drug therapy for most of its patients. Individual psychotherapy is virtually nonexistent ( 25 of 1,167 patients are in treatment at a time), and only 35 patients are currently in group therapy. ${ }^{5}$

The inability of Farview's staff to provide adequate care adversely affects many persons committed there. The following condemnation of Michigan's Ionia State Hospital is an apt description of analogous treatment given at Farview.

\section{Many of the patients at Ionia State Hospital do not} consider it a hospital but rather a prison and, in fact, an ex-

1 Mental Health Act of $1951, \S 1230$ (b) ; No. 444, [1963] Pa. Laws 976-77, amending No. 581, [1952] Pa. Laws 2059 (repealed effective July 1, 1969). For an extensive description of Farview State Hospital, see Note, Hospitalization of Mentally Ill Criminals in Pennsylvania and New Jersey, 110 U. PA. L. REv. 78 (1961) [hereinafter cited as Note, Hospitalization of Mentally Ill Criminals].

2 Interview with John Moran, Director of Social Services at Farview, Feb. 7, 1969.

3 Id. Letter from Dr. Bernard J. Willis, Clinical Director at Farview, to Bert Hoff, Apr. 2, 1969, on file at Biddle Law Library at the University of Pennsylvania.

4 "Milieu" therapy is the imposition of a structured and ordered environment on a patient who is unable to provide the internal structure which enables "normal" people to live in a complex society and environment. See, Note, Hospitalization of Mentally IIl Criminals, supra note 1 , at 86 .

o It is difficult to persuade many more patients than this to participate in the group therapy program. Interview with John Moran, supra note 2 . 
tremely undesirable prison. For the majority, it is a prison to which one is committed on an arbitrary and incomprehensible basis; it is a prison in which apparent medical functions are carried on in a mechanical fashion without reference to any previous or future framework; it is a prison in which hopes of release gradually are transformed into despair and finally into psychotic delusions. The Ionia atmosphere is predominantly composed of feelings of uncertainty and insecurity. Such feelings have their origin in, and are reinforced by, the uncertainty of the statute, the uncertainty in the mind of the court, and the uncertainty in the minds of the examining physicians. Uncertainty continues at the hospital in the minds of the patient and the doctors.

What of the patient? How does he react to the uncertainty and the endless drifting to which he is subjected? The answer is simple: he becomes sicker. The records studied at Ionia are replete with examples of patients who in the initial stages of their hospitalization made significant improvement. However, because such improvement was not measured against any therapeutic framework or applied to any definite goal other than vague concepts of social competency or "restoration to sanity," it passed almost unnoticed. At such a time the patient is struck by the realization that his chances of release are remote. His already sick and flimsy personality structure collapses and the frightening hostility and desolating worthlessness against which the patient has struggled are intensified. Possibilities of mental health become more remote. Questions of parole or discharge become academic. The picture of the gradually decreasing frequency of the doctors' visits and the less frequent staff interviews looms large. Concepts of incurability are considered by both patient and hospital staff. Many human beings are lost, not a dozen or fifty, but literally hundreds, to themselves and to society. ${ }^{6}$

The Pennsylvania courts, then, when deciding whether to commit a person to Farview, must consider the depressing reality that Farview offers: that is, a likely reversal in a patient's progress toward mental health.

In addition to this undesirable aspect, the courts must also face the probability that persons committed to Farview are likely to remain incarcerated for a period in excess of any penal sanctions the state could impose. This situation becomes extremely poignant when the

- Comment, Competency to Stand Trial, 59 MicH. L. REv. 1078, 1091-92 (1961); cf. Hess \& Thomas, Incompetency to Stand Trial: Procedures, Results and Problems, 119 Asr. J. Psych. 713 (1962). 
court commits a person awaiting trial as incompetent to stand trial. Virtually all persons found incompetent to stand trial are committed to Farview or to a maximum security or criminal ward of a state hospital until competent or restored to sanity. ${ }^{7}$ Of the 1,167 patients at Farview, 518 were committed under criminal charges prior to trial. The records of the Director of Farview indicate that as of October 13, 1968, 53 persons from Philadelphia were at Farview, "awaiting trial, sentence, or other judicial disposition by the Philadelphia County Court." 8 Of these, the status of one is unclear, and 4 appeared at Farview substantially after the charges on which they await trial were brought. ${ }^{9}$ The remaining 48 appear to have been sent directly to Farview to be held as incompetent to stand trial. In addition, the Prison Research Council of the University of Pennsylvania Law School has questionnaires from 2 persons from Philadelphia County, being held at Farview as incompetent, whose names do not appear on the director's records. Of the 48 patients from Philadelphia sent directly to Farview and on the director's records as awaiting trial, 16 have been incarcerated longer than they would have been had maximum sentence been imposed and cumulated on a finding of guilty on all indictments with which they were charged. The following table gives an indication of the longevity of detention.

\section{TABLE I}

Number of persons ${ }^{\mathrm{A}}$ incarcerated 2 times maximum cumulative sentences ................

Number of persons ${ }^{A}$ incarcerated 3 times maximum cumulative sentences ................

Number of persons ${ }^{\text {A }}$ incarcerated 4 times maximum cumulative sentences $\ldots \ldots \ldots \ldots \ldots \ldots$.

Number of persons ${ }^{\text {A }}$ incarcerated 5 times maximum cumulative sentences ................

Number of persons ${ }^{A}$ incarcerated 6 times maximum cumulative sentences ............. 4

$$
\text { Total ................ } \overline{48}
$$

A These figures do not include one patient incarcerated 21 years on a "surety of the peace." Nor do they include 14 persons charged with murder, who may receive a life or a death sentence should they go to trial.10

7 A. Goldstein, The Insanity Defense 38 (1967) [hereinafter cited as GoldsteIN]; Note, Incompetency to Stand Trial, 81 HARV. L. ReV. 454, 455 (1967).

8 Letter from Dr. Shovlin, Director of Farview, to Arlen Specter, District Attorney of Philadelphia, Oct. 13, 1968.

These defendants were probably committed elsewhere and administratively transferred to Farview.

10 The 14 accused of murder have been at Farview an average of 13.3 years. The 3 longest terms of incarceration are 39 years and 9 months, 38 years and 3 months, and 25 years and 2 months. There is no way of telling how many of the 14 would have been found guilty of a lesser charge, found not guilty by reason of insanity, or otherwise acquitted. 
Furthermore, were maximum concurrent sentences imposed on all outstanding charges, 19 prisoners would receive sentences shorter than the length of time they already have been incarcerated.

A few case histories will adequately demonstrate the hopeless plight of some Farview patients committed as incompetent to stand trial. A man indicted for robbery (which has a maximum sentence of 10 years ${ }^{11}$ ) was sent to Farview in 1936. There he remains, ostensibly waiting to go to trial. A fellow patient, accused of assault and battery, was sent to Farview about $19 \mathrm{I} / 2$ years ago, while the maximum term of imprisonment for assault and battery is only 2 years. ${ }^{12}$ A shoplifter who struggled with police after being apprehended was sent to Farview in 1951. Although the maximum terms of imprisonment for shoplifting and resisting arrest are 90 days ${ }^{13}$ and one year ${ }^{14}$ respectively, this patient is still being detained. Another man, charged with assault and battery with intent to kill, which carries a maximum penalty of 7 years, ${ }^{15}$ has been at Farview for almost 19 years.

If a patient received adequate and effective treatment at Farview, this type of extended incarceration might be justified. But the penal atmosphere of Farview tends to hinder recovery. ${ }^{16}$ Many prisoners at Farview view their incarceration with jaundiced eyes. ${ }^{17}$ The state has formally accused them of a crime, yet refused to bring them to trial in an open court and permit them to assert their defenses. When they enter Farview, they come into contact with persons who have been incarcerated there for thirty years. They soon realize that almost as many people leave Farview in a pine box as are formally discharged. ${ }^{18}$ They begin to feel that the state will keep them secreted at Farview, far away from their homes and friends, for the rest of their lives. They also realize that little or no treatment is available. Finally, insult is added to injury. Sections 501 and 502 of the Mental Health \& Mental Retardation Act of $1966^{19}$ impose liability upon them and those who have a legal duty of support for costs they incur.

It is no wonder, then, that the hospital is seen by many psychotic paranoids as the chief instrument in a governmental conspiracy against

11 PA. Stat. ANn. tit. 18, $\$ 4704$ (1963).

$12 I d . \S 4708$.

13 Id. $\$ 4816.1$ (Supp. 1969).

14 Id. $\$ 4314$.

${ }^{15} I d . \$ 4710$ (1963).

16 Note 37 infra \& accompanying text.

17 These views of Farview were expressed by prisoners in letters written to the Prison Research Council, University of Pennsylvania Law School, on file at the Prison Research Council.

The debilitating aspects of hospitalization are described graphically in Hess \& Thomas, Incompetency to Stand Trial, supra note 6.

${ }^{18}$ Appendix B in Note, Hospitalization of Mentally Ill Criminals, supra note 1, indicates that between 1945 and 1960,719 patients were released from Farview while 510 died there.

19 Pa. Stat. ANn. tit. 50, $\$$ 4501-02 (Supp. 1969). 
them. In this situation, treatment in any meaningful sense is impossible. When a patient has only been charged with a crime and has not been proven dangerous to society or himself, the wisdom of committing him to an institution of a penal nature, which may further impair his mental abilities, is certainly open to question. Bearing in mind the illusory therapeutic value of Farview, this Comment will discuss the purposes of commitment for incompetency and analyze the Pennsylvania laws governing it.

\section{Standards for ComMitment}

The common law standard for competence to stand trial is whether the accused can comprehend the nature of the proceedings against him and assist his attorney in making a rational defense. ${ }^{20}$ However, in Pennsylvania the matter has not been that simple. The standard of competency has undergone a convoluted development.

In Commonwealth v. Moon, ${ }^{21}$ the Supreme Court of Pennsylvania faced the question whether Pennsylvania's "Mental Health Act of 1951 changed the common law test for staying criminal proceedings after the verdict but prior to sentence or execution." 22 After Moon had been found guilty of first degree murder, sentenced to death, and imprisoned in the Warren County Jail, the county sheriff petitioned the trial court to appoint a sanity commission under section 344 of the Mental Health Act of $1951 .^{23}$ The commission found that Moon was mentally ill and suffered from "dementia praecox of the paranoid type" ${ }^{24}$ but that he understood the nature and meaning of his trial and sentence. The trial court found that since Moon understood the nature of his trial and could assist his attorneys, he was legally sane.

The supreme court reversed on the ground that the trial court erred by applying the common law standard of competency. Section 344 provided for a petition for commitment of any person "[d] etained in any penal or correctional institution who is thought to be mentally ill or in such condition that he requires care in a mental hospital . . . ." 25 Under section 345 of the Act of 1951, the trial court was to commit the person if the court was satisfied that he was mentally ill. The Act in section $102(11)^{26}$ defined mental illness as "an illness which so

20 Commonwealth v. Moon, 383 Pa. 18, 23, 117 A.2d 96, 99 (1955).

21383 Pa. 18, 117 A.2d 96 (1955).

22 Id. at 20, $117 \mathrm{~A} .2 \mathrm{~d}$ at 98.

23 No. 581, [1952] $\mathrm{Pa}$. Laws 2065, anending No. 141, [1951] Pa. Laws 555-56 (repealed effective July 1, 1969).

$24383 \mathrm{~Pa}$. at 21, 117 A.2d at 98.

25 No. 581, [1952] Pa. Laws 2065, anending No. 141, [1951] Pa. Laws 555-56 (repealed effective July 1, 1969).

26 No. 581, [1952] Pa. Laws 2055, amending No. 141, [1951] Pa. Laws 539 (repealed effective July 1,1969 ). 
lessens the capacity of a person to use his customary self-control, judgment and discretion in the conduct of his affairs and social relations as to make it necessary or advisable for him to be under care." ${ }^{27}$ Since the trial court had applied the common law standard of competency, rather than the statutory standard of mental illness, the supreme court remanded the case to allow the trial court to determine whether Moon's mental illness so lessened his mental capacities as to render commitment necessary or advisable, with the final decision resting exclusively in the court.

The Moon standard of mental illness was not limited to that case's narrow factual setting, which involved an alleged incompetent awaiting execution for murder. ${ }^{28}$ Section 344 of the Act of 1951 expressly applied to persons detained in any penal institution and not simply to convicted murderers. Consequently, the Moon standard of competency was applicable to all persons detained in a penal institution who were being considered for commitment as incompetent to stand trial.

The class of mentally ill persons for whom commitment is advisable or necessary, and who may be committed under the terms of the Mental Health Act of 1951, is much larger than the class of persons who are so out of touch with reality that they cannot understand the nature of the proceedings against them and assist their attorneys, and who could therefore be committed under the common law standard. The two groups are not to be taken as congruent, by any means. ${ }^{29}$ A paranoid schizophrenic who was "commanded by God" to murder someone in order to thwart a massive government conspiracy, or whose crime otherwise arises out of his delusional system, will so confuse reality with fantasy as to be unable to advise his attorney about the facts of the crime. However, even a person who believes God directed him to kill someone, who feels he is the victim of a massive conspiracy, or for some other reason is unable to tell his attorney why he committed the crime, may be able to tell the lawyer how and when he did it, and thus may not be committed under the common law standard. ${ }^{30}$ But mental illness is much more subtle. There are many psychotics who function quite normally over a broad spectrum of human affairs. Most psychotics would

27 Id.

$28 \mathrm{Cf}$. Commonwealth ex rel. Cummins v. Price, 421 Pa. 396, 218 A.2d 758, cert. denied, 385 U.S. 869 (1966).

29 See Amrerican Bar Foundation, The Mentally Disabled and the Law 360 (1961) ; Carroll \& Leopold, The Current Influence of P sychiatric Concepts in Determining Criminal Responsibility in Pennsylvania, 31 TEMP. L.Q. 254 (1958); Note, Incompetency to Stand Trial, supra note 7 , at 459 .

$30 \mathrm{~A}$ patient observed by the author at a staff presentation at Norristown State Hospital believed that God commanded him to stab his landlady and commit suicide in order to thwart a Communist-Nazi conspiracy to overthrow the government. He was able to relate the events which transpired at the time of the crime with a great degree of lucidity. There was no doubt that he was extremely ill, yet he was able to stand trial and conducted an adequate defense. 
be able to relate the facts of their case, assist their attorneys in their defense, and make rational strategic decisions during their trial. ${ }^{31}$

This change in the statutory standard of competency to stand trial, which was substantially similar to the standard for civil commitment, ${ }^{32}$ was hailed in some quarters as an enlightened change permitting proper inquiry into the real issue in incompetency proceedingswhether the accused should be committed at this time. ${ }^{33}$ Such a rule would enable more people to be placed in the rehabilitative, rather than the penal, system than the narrower M'Naghton" ${ }^{34}$ "knowledge of right and wrong" test would have allowed. ${ }^{35}$ However, the effect of liberalizing the standard of commitment on persons charged with a crime and then committed as incompetent to stand trial was less than beneficial in Pennsylvania. ${ }^{36}$ Farview is able to offer little or no treatment. The isolation of a defendant in a remote area of Pennsylvania for a protracted period has the immensely antitherapeutic effect of dissolving ties with family and friends in his home town. Furthermore, treatment is much more difficult when the charges are still outstanding than in the case where the patient is tried as soon as possible and treatment begun after sentencing or acquittal. ${ }^{37}$ A fundamental problem in any psychosis

31 In the summer of 1968 the author participated in a 2 month clinical training program in psychiatry. One day a pleasant, vivacious, intelligent, apparently normal woman of about 40 was interviewed. After 15 minutes of amiable conversation, she commented that she was afraid to use the bathroom facilities in the ward because she felt her karma (life-force which determines destiny in one's next existence) was in the plumbing and would be forever lost. It is doubtful whether her grandiose delusional system or failure in reality-testing in this limited sphere would interfere with her competency to stand trial, were she accused of a crime.

32 See No. 648, [1961] Pa. Laws 1529, amending No. 581, [1952] Pa. Laws 2063 (repealed effective July 1, 1969).

$33 \mathrm{H}$. Weihofen, Mental Disorder as a Criminal Defense 428 (1954); Borden, Hospitalizing the Mentally Ill in Pennsylvania, 33 TEMr. L.Q. 165, 167, 195 (1960); Slough \& Wilson, Mental Capacity to Stand Trial, 21 U. PITT. L. REv. 593, $597-98(1960)$.

34 M'Naghten's Case, 8 Eng. Rep. 718 (H.L. 1843).

35 See Slough \& Wilson, Mental Capacity to Stand Trial, supra note 33;29 Temp. L.Q. 389, 391 (1956); cf. Borden, Hospitalizing the Mentally Ill in Pennsylvania, supra note 33 , at 200-01.

36 See AmErican Bar Foundation, supra note 29, at 359-60; Goldstein, supra note 7, at 185-220; Vann, Pretrial Determination and Judicial Decision-Making: An Analysis of the Use of Psychiatric Information in the Administration of Criminal Justice, 43 U. DET. L.J. 13, 32 (1965) [hereinafter cited as Vann]; Note, Incompetency to Stand Trial, sipra note 7, at 459-61. See also Morris, Psychiatry and the Dangerous Criminal, 41 S. CaL. L. Rev. 514, 522 (1968) [hereinafter cited as Morris].

37 Interviews with Dr. Edward B. Guy of the Maximum Security Forensic Diagnostic Hospital, at Holmesburg, Pa., Jan. 15, 1969; Dr. Richard G. Lonsdorf of the faculty of the University of Pennsylvania Law School and staff of the Hospital of the University of Pennsylvania, Jan. 15, 1969; and Dr. Bernard J. Willis \& Dr. W. H. Horan of the staff of Farview State Hospital, Feb. 7, 1969; cf. Morris, supra note 36, at 525 , which states:

Prison authorities regard their inmates in the facilities for the psychologically disturbed as both criminal and insane, bad and mad; mental hospital authorities regard their inmates who have been convicted-or only arrested and charged with crime-as both insane and criminal, mad and bad. While examining records in state mental hospitals, I occasionally find notations in red ink to 
is the patient's inability to view or to assess meaningfully the reality of his situation. He is out of touch with the world around him. As long as the charges remain, and the issue of guilt is unlitigated, the patient does not have to cope with the circumstances surrounding the crime. Disposition of the charges forces the patient toward a better understanding of reality. Furthermore, what some psychotics seek most fervently in their chaotic environment is certainty and order-an anchor in the real world. ${ }^{3 s}$ The person who has been at Farview for thirty-three years may be unable to find certainty and order when

the effect that this person has been arrested for a crime. Discussion with the relevant authorities reveals that the red ink notation seriously influences the date of his likely discharge. Note that an arrest without a conviction has this effect.

Contra, Interview with Dr. C. Fred Herring of the Psychiatric Clinic of the Probation Department of the Court of Common Pleas and Quarter Sessions of Philadelphia, Pa., Jan. 22, 1969, where he stated that it is preferable to dispose of the cases of persons who will require long-term treatment by continuing the "incompetency" commitment rather than nolle prossing the charges and civilly committing the patient. In the former, a court must review the case before a patient is released onto the street; thus, there is an additional safeguard against letting a potentially dangerous patient loose before he is ready. In addition, the requirement of court approval for partial release or out-patient care gives the treating psychiatrist additional leverage (i.e., a court-ordered arrest of the patient), to secure compliance with a treatment plan.

The most deleterious hardship imposed on a patient not competent to stand trial is that Farview is severely limited in the number and flexibility of treatment plans available for the patient. As a result of a conference of superintendents of state mental hospitals which was held at Farview in September of 1963, state hospitals no longer refuse to admit any transferee from Farview who has criminal charges pending. However, hospitals are still reluctant to accept these patients. See note 120 infra. Further, Farview is much more cautious and selective in determining which patients with charges pending are to be transferred than in the case of civilly committed patients.

Two examples will serve to highlight the problems in securing the transfer of patients. A patient suffering from paranoid schizophrenia has been at Farview since 1957 , charged with indecent assault. He continues to need long-term hospitalization. Were it not for the outstanding charges, he could be transferred to a Veterans Administration hospital for appropriate treatment in a more suitable environment. However, $\$ 415$ (a) of the Mental Health \& Mental Retardation Act of 1966, PA. STAT. ANN. tit. 50, $\$ 4415$ (a) (Supp. 1969), prohibits the transfer to a Veterans Administration hospital, or to a hospital in another state, of any patient who has pending criminal charges. Another patient, a "chronic undifferentiated" schizophrenic also in need of long-term hospitalization, has been at Farview since 1960. Charges pending in the Juvenile Division include statutory rape, sodomy, and assault and battery with intent to kill. It is clear that he will not improve in the near future. Yet $\$ 415$ prevents the hospital from tranferring the patient to a mental hospital in Puerto Rico where he would be near his family.

The problems in flexibility of treatment are not limited to those of ease of administrative transfer. Farview's location makes the employment of out-patient or "work out, sleep in" treatment plans all but impossible. Even if Farview were more favorably located, neither these programs nor a leave of absence may be permitted without court order. PA. Stat. ANN. tit. 50, \$\$ 4406(b), 4408(e) (Supp. 1969). The problem is not merely one of red tape; many judges are more reluctant to permit these "uncured" individuals to walk the streets than are physicians.

38 For a vivid description of the dissolution of the world of a psychotic and subsequent construction of a delusional system to "structure" reality, see $H$. GREEN, I NEVER Promised You a Rose Garden (1964); T. Rubin, Cat (1965).

During the clinical training program described, note 31 supra, the author had occasion to observe an interview with a teenage girl whose world had slowly crumbled into total disintegration and whose mind had not yet imposed any kind of organization or structure on the world around her. Her sense of helplessness, confusion and fear as her world slipped away was overwhelming. 
he has charges outstanding which may require him to serve a five year sentence. Thus, in order to facilitate treatment, it is necessary to dispose of the criminal charges as soon as possible. ${ }^{39}$ Yet, the broadened Moon standard permits commitment of a greater number of persons charged with a crime than did the common law standard. As a result, a greater number of mentally ill persons are committed to Farview under circumstances which tend to impair their recovery.

In 1963, the Pennsylvania legislature addressed itself to the problem of returning to trial persons who had previously been committed as incompetent to stand trial. Section 347 of the Mental Health Act of $1951^{40}$ originally provided for the return to court of a person committed while awaiting trial "[u]pon his recovery or sufficient improvement of condition." 41 The legislature amended this section to require his return to court "[a]s soon as his condition has improved sufficiently to enable him to participate intelligently in his own defense " 42 However, no change was made in section 344 which dealt with petitions for commitment of persons detained in penal institutions who were or were thought to be mentally ill. The 1963 amendment created a statutory inconsistency in the treatment of persons awaiting trial. The Moon standard of commitment was broader than the common law standard apparently enacted in 1963. Thus, a person who, although mentally ill, could participate in his own defense could be committed as mentally ill and then released immediately to stand trial unless the phrase "participate intelligently in his own defense" was intended as the standard for commitment. The Mental Health \& Mental Retardation Act of $1966^{43}$ clarified this position. Section 408, concerning persons detained in prison, essentially returned to the common law test for commitment. That section stated:

In making such order for commitment the court shall give due regard to the capacity of such person to understand the nature and object of the proceedings against him, to comprehend his own condition in reference to such proceedings, to understand the nature of the punishment which might be inflicted upon him, to confer with his counsel with reference to such proceedings, to make a rational defense, and the probable effect of the trial on such person's physical and mental condition. ${ }^{44}$

39 See generally Temple University Unit tN LAW and Psychiatry, Standard Legar Procedures in the Disposition of Mentally ILl Offenders 16-17 (1968) (prepared for the Psychiatric Division of the Department of Probation of the Courts of Common Pleas and Quarter Sessions of Philadelphia) [hereinafter cited as CoURT Cinnic Manual].

40 See No. 581, [1952] Pa. Laws 2067, amending No. 141, [1951] Pa. Laws 556 (repealed effective July 1, 1969).

41 Id.

42 No. 429, [1963] Pa. Laws 896 (repealed effective July 1, 1969).

43 Pa. Stat. ANN. tit. 50, $\$ 4101-704$ (Supp. 1969).

44 Id. $\S 4408$ (d). 
However, under section 407 of the 1966 Act, ${ }^{45}$ a person released on bail is to be committed "in the same manner as if he had not been so charged with crime." The standard for civil commitment under the 1966 Act is substantially similar to the Moon standard. ${ }^{46}$ Although the standards for commitment as incompetent to stand trial differ between persons released on bail and persons detained in a penal institution, the standard for return to court is "a sufficient improvement of condition so that [the patient's] continued commitment is no longer necessary . . . " 47 This implies that the person released on bail has to travel further on his road to recovery than does the person detained, since he has to overcome his mental disability rather than merely meet the common law standard of competency to stand trial. Nevertheless, the 1966 Act has eliminated the possibility of a commitment followed by an immediate release.

The case law concerning standards for incompetency to stand trial does not reflect these statutory developments. In Commonwealth v. Ballem, ${ }^{48}$ decided in 1956, the Pennsylvania Supreme Court held it was not reversible error for a court to deny defendant's motion for commitment to a mental hospital in response to a report by psychiatrists that the defendant was able to understand the proceedings against him and assist counsel in his defense despite his mental illness. The trial court, after considering the report and exercising its independent judgment on the question, found that it was unnecessary to commit the defendant and that he was competent to stand trial. The supreme court affirmed on the ground that Moon required commitment for mental illness only when the trial court found that the defendant's mental illness made his commitment necessary or advisable.

However, in 1965 the court incorporated the common law standard of competency to stand trial into the Moon standard of mental illness. In Commonwealth ex rel. Hilberry $v$. Maroney, ${ }^{49}$ the court remanded a petition for a writ of habeas corpus to the court of common pleas in order to determine whether a self-confessed murderer was mentally ill at the time he entered his guilty plea. The court declared that the petitioner would be mentally ill if he was "unable to comprehend his position as one accused of murder and to co-operate [sic] with his counsel in making a rational defense . . . ." 50 Ironically, the court cited the Mental Health Act of 1951 and Moon, inter alia, for this definition of mental illness. On a subsequent appeal from the trial

$45 I d . \S 4407$ (a).

46 See id. $\$ 4406$.

47 Id. $\S 4409$ (b).

48386 Pa. 20, 123 A.2d 728, cert. denied, 352 U.S. 932 (1956).

49417 Pa. 534, 207 A.2d 794 (1965).

50 Id. at 544, 207 A.2d at 799. 
court's dismissal of the petition, the supreme court affirmed the common law standard of competency. ${ }^{51}$

The issue of which competency test should be used was further confused by the subsequent decision in Commonwealth ex rel. Cummins v. Price. ${ }^{52}$ There the defendant was sane and competent, but had received an injury at the time of the murder with which he was charged. This injury had caused permanent amnesia regarding circumstances surrounding the crime. The Pennsylvania Supreme Court declared that there are two complementary standards for competency in Pennsylvania. ${ }^{53}$ The court held, inter alia, that the Moon standard only applies when the defendant is mentally ill within the definition found in the Mental Health Act of 1951 and he is in need of hospitalization and commitment. The court found the defendant competent under the Moon standard since he did not need, nor had he or the trial court requested, hospitalization for mental illness. It also held that the defendant was not incompetent under the common law standard. Thus, Cummins seems to return to the Moon standard of competency whenever the accused falls within the 1951 Act's definition of mental illness. Yet Hilberry applied the common law test of competency to a petitioner alleged to be mentally ill.

Despite these conflicting opinions on the part of the supreme court, the standard presently applied in Pennsylvania is the common law standard ${ }^{54}$ A survey of the competency reports on file in the office of the District Attorney of Philadelphia ${ }^{55}$ revealed that these reports invariably contain conclusory language that the patient does or does not meet the common law criteria. The criteria for determination of competency utilized by the Department of Probation of the Courts of Common Pleas of Philadelphia are "the ability of the defendant to understand the nature of the proceedings, to communicate with counsel in his own defense, and the relevant criteria of the Mental Health Act" 56 which, again, is a clear reflection of the common law criteria.

\section{Procedures for Commitment}

Under the Mental Health Act of $1951,{ }^{57}$ persons charged with a crime could be recommended for commitment by designated officials or by any responsible person. Section 342 of the Act ${ }^{58}$ authorized the

$51424 \mathrm{~Pa} .493,495,227$ A.2d 159, 160 (1967). See also Commonwealth ex rel. Epps v. Myers, 197 Pa. Super. 145, 148-49, 177 A.2d 28, 29 (1962) (dictum-test for competency to stand trial is common law standard).

52421 Pa. 396, 218 A.2d 758, cert. denied, 385 U.S. 869 (1966).

$53 I d$. at $404 ; 218$ A.2d at $762-63$.

54 Interviews cited note 37 supra.

55 Survey of the files of the District Attorney of Philadelphia conducted by Bert Hoff, in Philadelphia, Pa., Dec. 12, 1968. [hereinafter cited as Survey]

58 Court Clinic Manual, supra note 39 , at 16-17.

57 No. 141, [1951] Pa. Laws 533. Since this act is repealed effective July 1, 1969, the commitments discussed in $\$ \S I$ and II of the text were made under this act.

58 No. 581, [1952] Pa. Laws 2065, amending No. 141, [1951] Pa. Laws 554 (repealed effective July 1, 1969). 
court to appoint a responsible person to petition for the civil commitment of any person appearing before the court who "appears to be mentally ill ${ }^{50}$ or in need of care in a mental hospital . . .." Section $344^{60}$ provided for a petition for commitment of any prisoner or any person released on bail. Under section 344(a)(1), if any "person detained in any penal or correctional institution . . . is thought to be mentally ill or in such condition that he requires care in a mental hospital," the prisoner's counsel, an executive officer of the institution, or any other responsible person may petition for the prisoner's commitment. The standard for commitment of a person on bail under section 344 (a) (2) was that he be "thought to be mentally ill."

After the court received a petition for commitment, section $345^{\mathrm{B} 1}$ required the court to order an examination of the person thought to be mentally ill. The examination must be conducted by two qualified physicians or by a commission comprising an attorney and two qualified physicians. The doctors or commission must give advance notice of their meeting to the patient's attorney and family. If, on receipt of the report, the court is satisfied that the accused is "mentally ill," it must notify these persons, who may request a hearing under section 345 (b). If none of these persons requests a hearing, the court under section 345 (c) may determine to conduct such a hearing on its own initiative.

The Mental Health \& Mental Retardation Act of $1966^{62}$ eliminates the dichotomy between defendants who appear to be mentally ill when they are present in court and defendants detained in prison or on bail who are the subject of a petition for commitment filed in the court. Instead, it establishes different procedures for defendants on bail and those who are detained in prison. ${ }^{63}$

59 Section 102(11) of the Act defined mental illness as follows:

"Mental illness" shall mean an illness which so lessens the capacity of a person to use his customary self-control, judgment and discretion in the conduct of his affairs and social relations as to make it necessary or advisable for him to be under care. The term shall include "insanity," "unsoundness of mind," "lunacy," "mental disease," "mental disorder," and all other types of mental cases, but the term shall not include "mental deficiency," "epilepsy," "inebriety," or "senility," unless mental illness is superimposed.

No. 581, [1952] Pa. Laws 2055, amending No. 141, [1951] Pa. Laws 539 (repealed effective July 1, 1969).

60 No. 152, [1957] Pa. Laws 297, amending No. 626, [1956] Pa. Laws 1897 (repealed effective July 1,1969 ). Section 344 was rewritten in 1956. The original language may be found at No. 581, [1952] Pa. Laws 2065-66, anending No. 141, [1951] Pa. Laws 555-56.

61 No. 141, [1951] Pa. Laws 556 (repealed effective July 1, 1969).

62 PA. Stat. ANN. tit. 50, $\$$ 4401-704 (Supp. 1969).

03 This procedural dichotomy between persons detained in a penal or correctional institution and those released on bail raises the constitutional issue of equal protection. Under $\S 407$ of the 1966 Act, proceedings to commit a person released on bail are the same as those for civil commitment. The lack of procedural safguards in these $\$ 407$ provisions represents a disturbing step backwards from the 1951 Act provisions relating to persons on bail. The minimal due process safeguards of the 1951 Act, that under $\S 345$ (a), No. 141, [1951] Pa. Laws 556 (repealed effective July 1, 1969), the court must notify the relatives and attorney of the accused of an examination report recommending commitment and that the relatives or attorney under $\$ 345(\mathrm{~b})$, id., may demand 
Section 407 (a), ${ }^{\beta 4}$ for example, outlines procedures to be employed where the defendant is on bail pending trial. It provides that a defendant who "is or becomes mentally disabled ${ }^{65}$ so that his admission or commitment to a facility is necessary" should be committed "in the same manner as if he had not been so charged with crime"; thus, a person released on bail is civilly committed. The provisions for civil commitment which are normally applicable to a person released on bail can be found in section $404^{66}$ (commitment directly to a hospital after application by a responsible person, accompanied by certificates of two physicians) and section $406^{67}$ (civil court commitment). There are no procedural safeguards in section 404 other than those providing that the superintendent of the hospital receiving the application must notify a relative or friend, ${ }^{68}$ and that the commitment must be reviewed at least annually by a committee selected from the hospital's staff. ${ }^{69}$ Civil proceedings under section $406^{\mathbf{7 0}}$ are begun by filing a petition for "immediate examination or commitment to an appropriate facility for examination, observation and diagnosis." 71 The petition must "set forth the facts upon which the petitioner bases his belief of mental disability . . . 72 The person sought to be committed must be examined by one or more physicians before the petition is filed, or, if the petitioner has not been able to have the patient examined prior to filing the petition, the petition must state "the efforts made to secure examination." 73 Upon receipt of the petition, the court must notify

an in-court hearing after the examination, have been entirely eliminated. Since the use of a commission has been abolished in civil commitment proceedings, there appears to be no way to permit a patient to "participate" in the examination rather than merely be examined. In view of the procedural safeguards which $\$ 408$, PA. STAT. Ans. tit. $50, \S 4408$ (Supp. 1969), provides for persons detained in a penal or correctional institution, text accompanying notes 78-86 infra, a high price is placed on the exercise of one's right to bail. The 1966 Act establishes an invidious discrimination between persons on bail and those detained for want of bail, which is in no way related to the purposes of the Act. No special circumstances of persons on bail, as opposed to incarcerated persons, warrants denying them the safeguards which the legislature recognizes must be granted to those in detention awaiting trial. Consequently, the failure of $\S 407$ to provide the same procedural safeguards to those released on bail that are provided by $\S 408$ to those detained, is a denial of equal protection and violates the fourteenth amendment.

64 Pa. Stat. Ann. tit. 50, \$4407 (a) (Supp. 1969).

65 The 1966 Act substitutes the term "mental disability" for the term "mental illness" used in the 1951 Act. However, the definition of "mental disability" in the 1966 Act, id. $\S 4102$, is substantially equivalent to the definition of "mental illness" in the 1951 Act. For the definition of "mental illness," see note 59 supra.

66 Pa. Stat. Ann. tit. 50, $\$ 4404$ (Supp. 1969).

67 Id. $\$ 4406$.

68 Id. $\$ 4404$ (c).

69 Id. $\S 4404$ (d). Section 426 of the 1966 Act, id. $\$ 4426$, provides that a petition for a writ of habeas corpus is available to a person committed by any procedure, and that the hospital has the burden of justifying the patient's continued detention.

70 Id. $\$ 4406$.

71 Id. $\$ 4406(\mathrm{a})$.

72 Id. $\$ 4406$ (a) (2).

73 Id. 
interested parties and hold a hearing. ${ }^{74}$ After the hearing the court may order an immediate examination by two physicians or commit the patient for up to ten days for examination. ${ }^{75}$ If examination reveals that "such person is in need of care at a facility," the doctors or superintendent of the hospital where the patient was committed for examination must so report to the court. ${ }^{76}$ The court may then order commitment "for care and treatment." 77 There is no provision for examination by a commission in a civil commitment; nor does the statute grant the patient any right to present his case at the examination. Neither is there provision for a hearing in court after the court receives the report of the examination.

The provisions for commiting a person detained in a penal or correctional institution contain certain procedural safeguards absent from the provisions for commitment of a person released on bail. A petition for the commitment of a person detained in jail before trial, under section $408,{ }^{78}$ may be presented to the court by a prison official, a relative of the prisoner, the prisoner himself, his attorney, or the "attorney for the Commonwealth." 79 Such person may file a petition when he believes the defendant to be "mentally disabled so that his commitment to a facility is necessary . . . ." so The court may then employ any or all of the following procedures: ${ }^{81}$ (1) an examination in jail by two or more physicians to determine whether the defendant is mentally disabled and whether commitment is necessary; (2) appointment of a commission to examine the accused in jail "and receive any other evidence from any source" 82 bearing on whether the person is mentally disabled and whether commitment is necessary; (3) appoint an attorney for the accused; (4) hold a public or private hearing after giving appropriate notice "to all interested parties." 83 A physician may request commitment for a period not exceeding sixty days for further

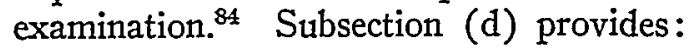

After consideration of the petition and all evidence presented, the court may order the commitment . . . if satisfied that the person is mentally disabled and that his commitment is necessary. In making such order the court shall give due regard to the capacity of such person to understand the nature and object of the proceedings against him, to comprehend his

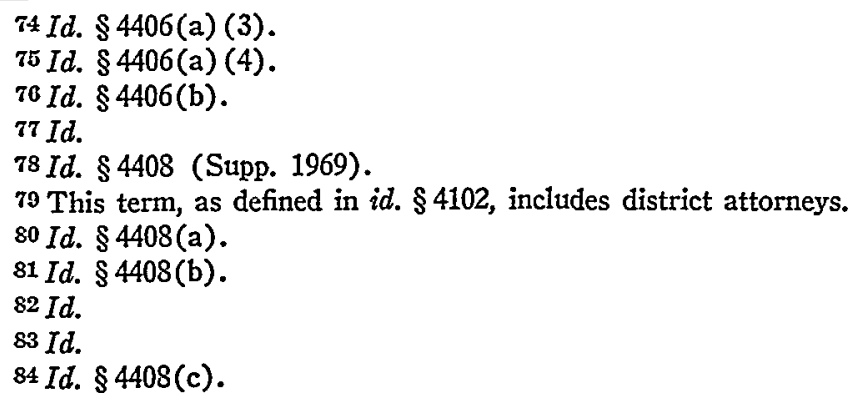


own condition in reference to such proceedings, to understand the nature of the punishment which might be inflicted upon him, to confer with his counsel with reference to such proceedings, to make a rational defense, and the probable effect of the trial on such person's physical and mental condition. ${ }^{85}$

It should be noted there is no similar language in section 407 . Unlike section 406 (civil court commitment made applicable to bail cases by section 407), section 408 permits the court to appoint a commission, appoint an attorney to represent the accused, and/or hold a hearing. The effect of these provisions is to permit the accused, in the discretion of the court, to present his case to the court and to challenge effectively the conclusions reached by the examining body. However, despite the seeming concern for safeguards in the confinement provisions, these are not guaranteed. In light of the possibility that an order of commitment following these proceedings may result in the commitment of the accused to Farview for an indeterminate period, one would expect these minimal procedural safeguards to be mandatory, rather than discretionary with the court. Providing only for challenge of commitment through the habeas corpus process may be much less effective than the right to challenge the proceedings as they are taking place since witnesses or vital evidence may be lost and the patient is necessarily deprived of his liberty prior to issuance of the writ. ${ }^{86}$

The procedures for committing a person charged with a crime may have constitutional infirmities. First, section 408 of the Act of 1966 pertaining to commitment of persons presently detained leaves in the discretion of the court the decision whether or not to grant a hearing on the prisoner's incompetency. In Pate $v$. Robinson, ${ }^{87}$ the trial court denied the petitioner a hearing on his incompetency to stand trial and convicted him of first-degree murder. The Illinois Supreme Court affirmed on the grounds that the petitioner failed to request a hearing, that the evidence was not sufficient to cause the trial court to order a hearing on its own motion, and that there was no reasonable doubt as to the petitioner's sanity at the time of the murder. ${ }^{88}$

On a hearing of a petition for habeas corpus, the United States Supreme Court found that "the uncontradicted testimony of Robinson's history of pronounced irrational behavior" 89 "entitled him to a hearing" ${ }^{90}$ on the issue of his competency to stand trial. To try and convict a defendant who is legally incompetent to stand trial is a violation of

85 Id. $\S 4408(2)$.

86 See Pate v. Robinson, 383 U.S. 375, 387 (1966) ; Dusky v. United States, 362 U.S. $402(1960)$.

87383 U.S. 375 (1966).

$88 I d$. at $376-77$.

$89 \mathrm{Id}$. at $385-86$.

$80 I d$. at 385 . 
due process : that is, he is denied his right to a fair trial. ${ }^{91}$ Consequently, the Court held when the evidence raises a reasonable doubt concerning the defendant's competency, denial of a hearing on his competency is an unconstitutional proceeding.

Since the Act of 1966 authorizes a hearing on the prisoner's competency at the court's discretion, the Act, to avoid conflict with Robinson, must be construed to mandate a hearing whenever the court faces a reasonable doubt as to the prisoner's competency to stand trial. Of course, Robinson does not hold that a prisoner is entitled to an opportunity to prove himself competent when there is evidence indicating his incompetency.

An analogous situation is presented when a defendant convicted of a sex crime is sentenced under a separate statute authorizing up to life imprisonment for dangerous or habitual sex offenders. In this situation, the defendant strives to prove that he is not dangerous or an habitual offender. In Specht $v$. Patterson, ${ }^{92}$ the Supreme Court considered the constitutionality of the Colorado Sex Offenders Act which authorized an indeterminate sentence for one who is found to constitute "a threat of bodily harm to members of the public, or is an habitual offender and mentally ill." "93 The Act did not provide for a hearing with right of confrontation and cross-examination. The Court found that the Sex Offenders Act was triggered by conviction of a sex crime and resulted in a new criminal charge with new findings of fact. As such, it was a criminal proceeding requiring the procedural safeguards mandated by the fourteenth amendment. ${ }^{94}$

Specht, of course, did not involve an individual committed as incompetent to stand trial, but its rationale is applicable to commitment cases. Commitment procedures are not triggered by a conviction. In fact, civil commitment procedures are utilized for the patient previously released on bail. Since a person charged with a crime, but not convicted, should not be subject to criminal proceedings, the Act of 1966 might be considered to provide greater procedural safeguards for persons detained than may be constitutionally required since commitment as incompetent is not penal, but therapeutic. However, as was documented earlier in this Comment, ${ }^{95}$ the therapeutic quality of an institution such as Farview is seriously in question. Therefore, the Specht doctrine is applicable if one can say (as the evidence certainly shows) that commitment to Farview is penal. ${ }^{96}$

$91 \mathrm{Id}$. at 378,385 .

92386 U.S. 605 (1967).

93 Id. at 607.

94 Accord United States ex rel. Gerchman v. Maroney, 355 F.2d 302 (3d Cir. 1966).

95 Text accompanying notes 1-19 supra.

98 Were Farview truly therapeutic then Specht would certainly not apply. Although In re Gault, 387 U.S. 1 (1967), demonstrates that the availability of due process safeguards does not hinge on the label "criminal" being applied to a proceeding, the fact remains that prisoners committed as incompetent are not committed as punishment 


\section{Raising the Issue of Pre-trial Commitment}

It is not entirely clear how the issue of the competency of a defendant to stand trial is most frequently raised. A survey of the files of the District Attorney of Philadelphia conducted December 12, 1968, ${ }^{97}$ indicates that in most recorded cases the issue was raised by the warden of a prison (or sometimes the Philadelphia General Hospital) where the defendant was incarcerated before trial. In a few cases, the issue was raised on motion by an assistant district attorney, or by the defense counsel. In one case, the district attorney and the defendant's court-appointed attorney visited the defendant in a jail cell and observed the defendant to be very withdrawn and quite obviously mentally ill. In two or three instances, the staff of a local mental hospital asked the district attorney to begin proceedings against an inmate who had attacked another inmate or member of the staff. The Philadelphia District Attorney's office has no established program for instituting proceedings against one suspected of being incompetent to stand trial; on the contrary, it is done infrequently on an ad hoc basis and usually in circumstances where a bizarre crime has occurred or a history of mental illness comes to the attention of an assistant district attorney. ${ }^{98}$ On the other hand, the district attorney routinely requests the Psychiatric Division of the Department of Probation of the Courts of Common Pleas of Philadelphia (referred to hereinafter as the Court Psychiatric Clinic) to give an incompetency examination to all persons charged with murder. ${ }^{99}$

Most incompetency hearings are commenced when prison officials have some reason to suspect that a defendant incarcerated in lieu of bail is incompetent. ${ }^{100}$ This may be revealed by bizarre behavior during the incarceration, discovered by the physician giving the routine

for the crime with which they are charged. It has been asserted that commitment for incompetency is merely an alternative means whereby the prosecution or court can dispose of criminal charges. See GoLDSTEIN, supra note 7, at 171-220; PRESIDENT's Commission on Law Enforcement and Administration of Justice, The ChalLENGE OF CRTME IN A FREE SocIETy 133-34 (1967). Actually, commitment as incompetent is 1 of 3 means of disposing of the person charged criminally; the other 2 are findings of innocence or guilt. If the individual is incompetent, to convict him is to deny him a fair trial in violation of the sixth and fourteenth amendments. Pate v. Robinson, 383 U.S. 375 (1966). If the court has a reasonable doubt about the prisoner's competence, he should not be tried. Where such doubt exists, commitment is not penal and should be treated as other civil commitments in the absence of more stringent, statutory procedures when the rehabilitating institution is truly therapeutic. However, this is certainly not the case with Farview.

97 Survey, supra note 55.

98 Interview with Jeff Brodkin, Assistant District Attorney of Philadelphia, in Philadelphia, Dec. 12, 1968.

99 Interview with Dr. C. Fred Herring, supra note 37.

100 Interview with Dr. Edward B. Guy, supra note 37.

About half of the requests for an incompetency examination received by the Court Psychiatric Clinic originate from the Holmesburg Detention Center, Holmesburg, $\mathrm{Pa}$. The remainder originate with the court upon motion by the prosecution or defense. Interview with Dr. C. Fred Herring, supra note 37. 
in-coming medical examination, or disclosed while recording the prisoner's medical history. It is apparent that violent prisoners, ones with markedly bizarre behavior, and extremely withdrawn patients are much more likely to come to the attention of prison officials than prisoners who may be mentally ill but who quietly serve their time and do not draw attention to themselves.

Prior to the establishment of the Court Psychiatric Clinic, competency examinations in Philadelphia were conducted more frequently by a commission than by two physicians. ${ }^{101}$ Since the clinic's establishment, however, the court invariably proceeds with an examination by the clinic's physicians. ${ }^{102}$ The court and the clinic both view the role of the clinic as that of an impartial "friend of the court" rather than a participant in the adversary proceeding. ${ }^{103}$ During the examination by the clinic, the doctors ask questions such as "Do you know what you are charged with?" and "Do you know what burglary is?" Evaluation is on the basis of the answers to these questions, general responsiveness, general mental status, and ability to understand the questions asked and to answer in a rational manner. The clinic's staff attempts to understand the dynamics of the person examined as well as his dangerousness. The Court Clinic Mamual, in discussing pretrial competency examinations, states :

Diagnosis and prognosis may include such relevant factors as weakness or strength of ego control, degree of impulsivity, potential for physical violence and need for follow-up consideration, rather than being limited to a broad, general conclusion of dangerousness at the pre-trial level. ${ }^{104}$

Because the staff of the Court Psychiatric Clinic considers it necessary to dispose of the criminal charges as soon as possible, the staff will resolve doubts about competency in favor of a finding of competency rather than incompetency. ${ }^{105}$ Although the examination is more extensive when the patient is charged with a serious crime, there is no conscious attempt to correlate the standard of competency to the intricacy of the crime. Findings generally include a statement of the defendant's competency (usually phrased in the conclusory language

101 Survey, supra note 55.

102 Interview with Dr. C. Fred Herring, supra note 37. Except where noted otherwise, the information in the remainder of this paragraph in the text originated in this interview.

103 For this reason, the staff of the Clinic avoids dealing with any material bearing on the patient's criminal responsibility, if possible, and also tries to avoid material concerning the offense with which the patient is charged.

104 Court Clinic Manual, supra note 39, at 7; see Comment, Competency to Stand Trial, 59 MICH L. REv. 1078, 1082 (1961) (stressing that psychiatrists frequently misconceive their role as protecting society or the patient rather than determining competency).

105 Interview with Dr. Edward B. Guy, supra note 37. 
of the common law test of competency), ${ }^{106}$ whether he should be committed, and to what institution he should be sent. Frequently, where the issue of competency is unclear, the clinic will request the judge to order a sixty-day confinement to the Eastern Diagnostic and Classification Center at Holmesburg, Pennsylvania, for further evaluation. Proceedings at Holmesburg are similar to those outlined above.

If the patient is found to be incompetent to stand trial, must he be committed to Farview State Hospital? Section 345(d) of the Mental Health Act of $1951,{ }^{107}$ concerning persons charged with or sentenced for a crime, required the court to commit persons found to be mentally ill or "found to have a criminal tendency" to "a State hospital for patients convicted of crime, charged with crime, or with criminal tendencies." Section 230(b) of the Act of $1951^{108}$ designated Farview as "exclusively devoted to the care of patients convicted of crime or with criminal tendencies." In 1963, the legislature amended this section to add to those patients committed to Farview "persons requiring maximum supervision." ${ }^{09}$ Consequently, under the 1951 Act, a person charged with a crime who was found incompetent to stand trial would be committed to Farview if he required "maximum supervision" or displayed "criminal tendencies." Section $102(4){ }^{110}$ defined "criminal tendency" as "a tendency to repeat offenses against the law or to perpetrate new offenses, as shown by repeated convictions for such offenses or tendency to habitual delinquency."

Judicial construction may have been responsible for the 1963 amendment. In Commonvealth $v$. Martin, ${ }^{111}$ the court based its finding of criminal tendencies on evidence that the defendant, charged on two counts of forcible rape, had been incarcerated as a juvenile delinquent, that he had been fined for disorderly conduct for being "improper" with a woman, and that a prosecution for assault with intent to ravish against him had failed due to the illness and subsequent unavailability of a prosecution witness. The court implied that four arrests, even without four convictions, indicated a tendency toward habitual delinquency. In Commonwealth v. Bechtel, ${ }^{112}$ the defendant, a college student, shot and killed another student in a dormitory as part of his plan to slaughter all dormitory residents. In addition to finding the

106 Survey, supra note 55.

107 No. 581, [1952] Pa. Laws 2066, 2067, amending No. 141, Pa. Laws 556 (repealed effective July 1,1969 ). Since the 1951 Act was in effect at the time this study was made, commitment procedures discussed herein were in large part conducted under the 1951 Act.

108 No. 581, [1952] Pa. Laws 2065, amending No. 141, [1951] Pa. Laws 546 (repealed effective July 1,1969 ).

109 No. 444, [1963] Pa. Laws 976, 977 (repealed effective July 1, 1969).

110 No. 141, [1951] Pa. Laws 538 (repealed effective July 1, 1969).

11126 Pa. D. \& C.2d 509 (Chester County Ct.), aff'd 197 Pa. Super. 602, 180 A.2d 101 (1962).

112384 Pa. 184, 120 A.2d 295 (1956). 
defendant clearly and homicidally insane, the supreme court found criminal tendencies in the defendant's homicidal thoughts as a child and in his attacking another man while serving in the Air Force, because the defendant mistakenly thought he had stolen some records. Apparently, the court feared the consequences of committing the defendant to any state hospital other than Farview which was the only maximum security hospital available under the 1951 Act at that time. In order to place the defendant in Farview, the court was forced to stretch the definition of criminal tendencies to include an obviously dangerous person. This lacuna in criteria for commitment to Farview was corrected in 1963 when the legislature extended Farview's domain to include persons requiring maximum supervision.

The provisions of section 342 of the 1951 Act, ${ }^{113}$ permitting the court to appoint any responsible person to petition for the commitment of any individual appearing before the court who "appears to be mentally ill," require civil commitment. A petition for civil commitment made under section 326 (c) as originally enacted ${ }^{114}$ had to designate the type of institution the mentally ill person required. The court then committed that person to the designated institution. ${ }^{115}$ Since Farview at that time treated only convicted criminals or those persons with criminal tendencies, civil commitment to Farview of a person appearing before the court was necessarily based on his criminal tendencies, which was an extraordinarily flexible standard. ${ }^{116}$ In 1961, the Pennsylvania legislature amended sections 326(c) and 328(c) of the 1951 Act ${ }^{117}$ with the result that the court assigned persons civilly committed to the Pennsylvania "Department of Public Welfare for treatment in an appropriate institution." Of course, Farview was the only appropriate institution for persons with "criminal tendencies."

Although the Act of 1966 completely revised the commitment system to a particular institution, the effects of the change are likely to be negligible in the near future. Under section 202(a), ${ }^{118}$ the Department of Public Welfare "shall operate all state facilities and shall assign such functions to each as the secretary shall prescribe." It seems unlikely that Farview's function will be changed significantly by the Department. Hopefully, other state hospitals will be adapted to treat those patients now committed exclusively to Farview in order to ameliorate the overcrowded conditions. Section $401(c)^{119}$ states:

113 No. 581, [1952] Pa. Laws 2065, anending No. 141, [1951] Pa. Laws 554 (repealed effective July 1,1969 ).

114 No. 141, [1951] Pa. Laws 552 (repealed effective July 1, 1969).

115 Id. 553.

116 Interview with Dr. C. Fred Herring, supra note 37. The staff of the Court Psychiatric Clinic has not been troubled with difficulties in finding legal justification for a diagnosis of criminal tendencies whenever the staff felt the accused was dangerous. Id.

117 No. 648, [1961] Pa. Laws 1529 (repealed effective July 1, 1969).

118 Pa. Stat. Ann. tit. 50, § 4202 (a) (Supp. 1969).

119 Id. $\$ 4401$ (c). 
Whenever a court commits any person under any provision of this act, it may commit such person directly to a facility willing and able to receive him; otherwise, the court shall commit to a designated local or State facility . . . .

Only Farview is presently "willing and able" to treat persons found incompetent to stand trial. Therefore, as a practical matter, there is no alternative to Farview. ${ }^{120}$

\section{StANDARDS For Release}

After commitment to Farview Hospital, a patient has two primary concerns: recovery of his mental health and his release. Recovery of competence is the central purpose for his commitment as incompetent; ${ }^{121}$ extraneous purposes, such as protection of society, can be achieved by use of the state's police power. ${ }^{122}$ The standards for commitment should be matched by the standards for release because the only valid purpose of commitment ceases when the patient recovers his competency. ${ }^{123}$ However, the Pennsylvania courts and legislature have created a standard under which a patient may only be returned to trial after he is sufficiently cured to return to society. Therefore, they have totally overlooked the more realistic standard: that is, when he has regained the ability to understand the nature of the proceedings against him and to effectively assist his counsel.

120 Although superintendents of hospitals other than Farview will not refuse to admit a transferee from Farview, they are extremely reluctant to admit someone against whom criminal charges are pending, primarily because they are highly sensitive to adverse community reaction. For example, in the summer of 1968, the Philadelphia news media and the Northeast Civic Association brought great pressure against the director of the Philadelphia State Hospital at Byberry, Pa, in reaction to a number of heinous crimes committed by patients who had escaped from that institution. To lessen the possibility of adverse community pressure, the directors are likely to reject patients charged with a crime. Interviews with Drs. Edward B. Guy \& C. Fred Herring, supra note 37.

121 See Greenwood v. United States, 350 U.S. 366, 375 (1956) ; Foote, $A$ Comment on Pre-trial Commitment of Criminal Defendants, 108 U. PA. L. REv. 832, 838, 841 (1960) [hereinafter cited as Foote]; Note, Incompetency to Stand Trial, supra note 7, at 461-65. This justification for detaining the patient in an institution fails if the institution does not provide the treatment necessary to restore competency. United States v. Klein, 325 F.2d 283 (2d Cir. 1963); Miller v. Overholser, 206 F.2d 415 (D.C. Cir. 1953).

122 See Morris, supra note 36 , at 525 :

The police power and the mental health power are surely sufficient separately to control questions of dangerousness and the maxima of state power over individual citizens. It is a mutually corruptive, potent source of injustice loosely and thoughtlessly to blend these two powers, and thus to gloss over in each the proper balance between state power and the freedom of the individual. . . .

Contra, Commonwealth v. Cook, $390 \mathrm{~Pa} .516,135$ A.2d 751 (1957).

123 In State v. Swails, 223 La. 751, 66 So.2d 796 (1953), the court held that a patient had a right to be tried if he met the common law standard of competency, even though on other criteria he would remain hospitalized. 
The Mental Health Act of 1951, as amended shortly after its enactment, provided under section $347^{124}$ for a stay of proceedings until the defendant's "recovery or sufficient improvement," at which time he was to be returned to court for "trial or such other disposition of such charges as the court may make." The Pennsylvania Supreme Court considered the release of a defendant committed prior to trial in Commonwealth v. Cook. ${ }^{125}$ In this case, the petitioner Cook had been committed to Farview in 1939 following his commission of a "brutal triple murder." In 1956, the director of Farview petitioned the court for an order discharging the defendant into the custody of the sheriff of Beaver County to stand trial on the ground that the defendant no longer required Farview's custodial and remedial care. The district attorney opposed the petition on the ground that the defendant was mentally ill and of doubtful competence. A court-appointed commission found that the defendant was still mentally ill and of criminal tendencies. The trial court, in refusing to release the patient, cited the fact that one of the purposes of the Mental Health Act was the protection of society from dangerously insane criminals and emphasized the possibility that the defendant would be acquitted of the three charges pending and thus would go free. ${ }^{126}$ The supreme court affirmed on the lower court's opinion, adding:

In substance, Cook's contention is that when one is committed to a mental institution because he is incapable of cooperating with his attorney in planning and presenting his defense he should be released and brought to trial when sufficiently recovered to assist his attorney in these matters. This has no application to the case at bar in which Cook was committed because of a type of mental incapacity which makes him liable to commit violent criminal misconduct if he is free from custody and restraint and is sufficiently irritated or provoked. The fact [sic] a person could assist his attorney in preparation for trial does not alone determine his sanity. ${ }^{127}$

Despite the fact that the primary purpose of the entire Mental Health Act of 1951 may be the protection of society from dangerously

124 No. 581, [1952] Pa. Laws 2067, amending No. 141, [1951] Pa. Laws 556 (repealed 1963).

$125390 \mathrm{~Pa} .516,135$ A.2d 751 (1957); accord Commonwealth ex rel. Fritz v. Farview State Hosp. Superintendent, 174 Pa. Super. 609, 101 A.2d 922 (1953).

$126390 \mathrm{~Pa}$. at $519-20,135 \mathrm{~A} .2 \mathrm{~d}$ at 753.

$127 \mathrm{Id}$. at $520,135 \mathrm{~A} .2 \mathrm{~d}$ at $753-54$.

The standard of competency at the time Cook was decided was the Moon test rather than the common law test. Text accompanying notes 20-26 supra. The Cook opinion may be read as deciding that the standard for release is identical to the standard for commitment, i.e., mental illness. If the case is read in that manner, it no longer has precedential value for the detained defendant because the test of his competency has since become his ability to understand the nature of the proceedings against him and to assist his counsel, i.e., the common law test. See text accompanying notes 43-44 supra. However, the Moon test still applies to persons released on bail who are committed under civil commitment procedures. 
insane defendants, the court should not have allowed the purpose of the entire Act to obscure the purpose of that portion of the Act concerning commitment for incompetency. The incompetent person may be no more dangerous than any sane individual; his commitment is first and foremost to prepare him for trial. That he has been charged with a crime does not, in itself, prove his danger to society. ${ }^{128}$ The supreme court should have taken into account the fact that a patient competent to stand trial may still be committed on civil grounds if he is acquitted of the crime but presents a continuing danger to society.

Section 347 of the 1951 Act was amended in $1963^{129}$ to require the patient's return to court "for the disposition of the charges" "[a]s soon as his condition has improved sufficiently to enable him to participate in his own defense." 130 The only case decided between the passage of the amendment and the enactment of the Act of 1966 is Commonwealth ex rel. Wolenski $v$. Shovlin, ${ }^{131}$ which was a habeas corpus petition by the patient seeking return to court for trial. The Court of Common Pleas of Delaware County ordered examinations by the Farview staff and an independent physician. The Farview report stated that the defendant "does not now have the capacity to conduct the criminal proceedings against him in a meaningful manner." ${ }^{132}$ The report of the osteopath from Philadelphia who conducted the independent examination made no mention of capacity to stand trial, but stressed that the patient was acutely psychotic and that the prognosis was poor. ${ }^{133}$ The trial court stated that to try the patient would be a useless formality because "the relator continues to be mentally ill." 134 The supreme court affirmed dismissal of the petition on the ground that the petitioner had failed to comply with the statutory procedures for release. The court stated in dicta that the petitioner would need an affidavit from an independent physician declaring that he was no longer mentally ill. ${ }^{135}$ The court's mental illness test for release ignored the statute's standard of competency set forth in section 347 .

128 See Commonwealth v. Jenkins, 21 Pa. D. \& C.2d 413 (Phila. County Ct. 1959).

129 See text accompanying notes $40-43$ supra concerning the statutory inconsistency created by this amendment.

130 No. 429, [1963] Pa. Laws 896 (repealed effective July 1, 1969).

131419 Pa. 35, 213 A.2d 327 (1965). (1965).

132 Brief for Appellee at 11-12, Wolenski v. Shovlin, 419 Pa. 35, 213 A.2d 327

133 Id. at 9-10.

134 Civil No. 13, 729 (Del. County C.P., Feb. 17, 1965).

135 See $419 \mathrm{~Pa}$. at 40 n.5, 213 A.2d at 330 n.5, where the court, citing 50 PA. Stat. ANN. $\$ 1075$ (1954), defined mental illness as

an illness which so lessens the capacity of a person to use his customary self-control, judgment and discretion in the conduct of his affairs and social relations as to make it necessary or advisable for him to be under care .... 
In 1966, the legislature appeared to return to the Cook test for release. Section $409^{136}$ of the Mental Health \& Mental Retardation Act of 1966 provides for the return to court "for trial or such other disposition of such charges as the court may make" of a person who "shows a sufficient improvement of condition so that his continued commitment is no longer necessary . . . ." The 1966 Act also contains a new provision which permits a prosecuting attorney to require the mental hospital to show cause why the accused should not stand trial. ${ }^{137}$

If the Pennsylvania courts continue to detain persons committed as incompetent until they are no longer dangerous to society, the patient may be deprived of his right of a speedy trial in violation of the sixth amendment. ${ }^{138}$ Since the purpose of committing a defendant as incompetent is largely to restore him to competence, and thus assure him of a fair trial, any detention beyond his regaining competence unnecessarily delays his trial. ${ }^{139}$ This delay can defeat the purposes of the guarantee of a speedy trial described by the Supreme Court:

This guarantee is an important safeguard to prevent undue and oppressive incarceration prior to trial, to minimize anxiety and concern accompanying public accusation and to limit the possibilities that long delay will impair the ability of an accused to defend himself. ${ }^{140}$

The antitherapeutic effects of failure to dispose of charges pending against a patient make the guarantee of a speedy trial particularly important. In the view of a patient at Farview, delaying his release for trial is oppressive incarceration which increases his anxiety. ${ }^{141}$ Both effects of delay defeat the purposes of the guarantee of a speedy trial. ${ }^{142}$ So long as a person committed as incompetent to stand trial is detained beyond regaining competence, the state is denying him this constitutional right. ${ }^{143}$

\section{Practical Aspects of Release From Farview}

The initial decision whether to release a patient and return him to court for disposition of the charges against him rests with the staff at

136 Pa. Stat. AnN. tit. 50, $\$ 4409$ (b) (Supp. 1969).

137 Id. $\$ 4409$ (c).

138 In Klopfer v. North Carolina, 386 U.S. 213 (1967), the Supreme Court held that the sixth amendment right to a speedy trial applies to the states through the fourteenth amendment. A similar right appears in PA. CoNST. art. $1, \S 9$.

139 See note 146 infra.

140 United States v. Ewell, 383 U.S. 116, 120 (1966).

141 Text accompanying notes 16-20 supra.

142 See generally Foote, supra note 121, at 838-39, 842; 108 U. PA. L. REv. 414 (1960).

143 Any interest the state may have in protecting society may be satisfied by civil commitment after disposing of the criminal charges. 
Farview. The patient is returned to court only if a "staff" conference 144 results in the conclusion that the patient is competent to stand trial. A "staff" may be requested by the patient or it may be held to answer an an inquiry by a court, prosecutor, or (not infrequently) the patient's family or attorney concerning the patient's status. Following an inquiry by any of the above persons, a "staff" will be held unless it is clear to the physician in charge of the patient's ward that there has been no change in the patient's condition since the last "staff." If a patient shows sufficient improvement, the physician in charge of the ward may order a "staff" without receiving an inquiry. ${ }^{145}$

There is no standard procedure for periodic formal staff review of the status of patients awaiting trial. ${ }^{146}$ All "staffs" are initiated in one of the ways outlined above. Necessarily, this process must be somewhat random. In 1968 , fewer than 500 staff conferences were held for a population of about $1200 .{ }^{147}$ About 120 of these were "intake diagnostic." 148 In a small number of cases, a person is reviewed twice in one calendar year. Thus, the number of persons whose status is formally reviewed in any given year is small. However, only in a very small number of the files which the author reviewed had there

144 A "staff" is a quasi-formal review of a patient's status by the entire treatment staff of the institution. The presenting physician presents a social history of the patient, his prior criminal record and history of treatment for mental illness, facts and circumstances surrounding his arrest and/or commitment, and the findings of earlier psychological tests and "staff" conferences. A psychologist then summarizes the results of the latest psychological tests. The patient is then brought into the room and asked questions by the presenting physician. When the presenting physician has finished, other members of the staff are free to ask questions of the patient. The patient is then dismissed and the staff discusses his status. Interview with Dr. John Moran, supra note 2.

$145 \mathrm{Id}$.

146 But see American Bar Foundation, The Mentally Disabled and the Law 367 (1961).

Frequent periodic mental examinations should be made of all defendants hospitalized as incompetent and those found presently competent should be returned promptly for further proceedings.

This would prevent an accused from languishing indefinitely in custody without the opportunity of reaching trial on the criminal charge-a charge of which he may very well be innocent. By permitting a trial as soon as possible after recovery, this procedure would go far toward securing the benefits of a speedy trial for both the defendant and the state.

147 Interview with Dr. John Moran, supra note 2. In 1967, there were 448 "staffs" which returned 21 patients to court. Focus: Voice of the Patients, June 1968, at 10. The results of all staff referrals in 1967 are:

Number of hospitalized patients recommended for discharge to the community .........................................

Transfer to civil hospitals $\ldots \ldots \ldots \ldots \ldots \ldots \ldots \ldots \ldots \ldots \ldots \ldots, \ldots \ldots \ldots, 43$

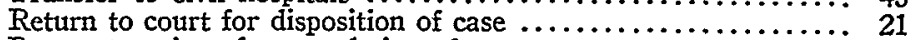

Return to prison for completion of sentence $\ldots \ldots \ldots \ldots \ldots \ldots \ldots, 17$

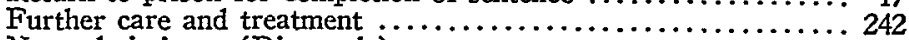

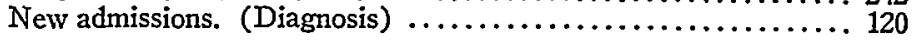

Total of patients diagnosed and evaluated for $1967 \ldots \ldots \ldots . \overline{448}$

148 The term "intake diagnostic" refers to a mental examination of incoming patients conducted during normal in-processing. 
been no "staff" in the last 5 years. Most of the files showed an evaluation within the last 2 years. ${ }^{149}$ Where there is no formal evaluation, the hospital relies on informal ward notes entered in the patient's file and on the general knowledge each doctor has of the status of every patient in the wards for which he has responsibility. There are about 500 personal doctor-prisoner contacts a month; ${ }^{100}$ the doctor also bases his general knowledge of the patients on oral reports and comments made to him by the custodial staff and various therapy department staff members. Philadelphia prisoners represented by the Defender Association have the benefits of an additional periodic review. A member of the Defender's Association of Philadelphia visits Farview about every three months. In addition to interviewing patients, he routinely reviews the files on men represented by his office. If there is any sign of improvement, he requests that the staff make a formal evaluation. ${ }^{151}$

The author observed two Farview staff conferences which considered patients' competency to stand trial. The first involved a twenty year old, white male who had been released on bail after an arrest for throwing a rock through a church window while drunk. Shortly thereafter, the patient was re-arrested for jaywalking in direct disobedience to a policeman's order. After tearing up his jail cell a few times, he was transferred to the local state hospital; the local hospital, unable to control him, transferred him to Farview in January 1969. He was diagnosed as having mild mental retardation and an explosive personality, but he had no signs of psychosis. There was no discussion of the patient's ability to confer with counsel or understand the nature of the proceedings against him. The staff reached the conclusion that the patient was incompetent, because they feared that he was close to a psychotic breakdown, and that the stress of trial would be too great for his explosive personality to handle. Moreover, one psychologist explained to me that the patient was unfit to stand trial because he was still too dangerous to be allowed on the streets.

The second "staff" reviewed the status of an eighteen year old, white male who stood accused of murder, burglary, larceny, receiving stolen goods, carrying a concealed deadly weapon, and a violation of the Uniform Firearms Act. He was sent to Farview after he made a suicide attempt in the Maximum Security Forensic Diagnostic Hospital at Holmesburg, Pennsylvania. A diagnosis of "anti-social personality with psychosis in remission" was changed to "aggressive personality

149 A significantly larger number of files contain no mention of a "staff" having been held between the time of commitment and about 1963 or 1964 . This may indicate a change of policy in favor of more frequent review. The staff of Farview is markedly more aware and cautious of their patients' legal rights than they were 5 years ago. Interviews with Dr. Moran, supra note 2, \& Dr. Willis, supra note 37.

150 Interview with Dr. John Moran, supra note 2.

151 Interview with Isaac Pepp, Defender's Association of Philadelphia, in Philadelphia, Pa., Feb. 6, 1969. 
(explosive personality) with incipient schizophrenia" in order to stress that the patient is not a sociopath, but that he is subject to violent outbursts and is on the verge of a psychotic breakdown.

The presenting physician asked the patient what crime he was charged with and asked questions about the nature of the proceedings. On the basis of the answers to these questions, as well as the patient's high intelligence, responsiveness and ability to give coherent, relevant answers to all the physician's questions, the staff decided that the defendant understood the nature of the proceedings and could assist his attorney in his defense. But then one physician expressed doubt whether it would be wise to return the patient for trial; he stressed that the patient needed treatment and would be unlikely to receive it in jail. Another pointed out that he had resisted treatment at Farview, so that availability of treatment might be irrelevant. It was suggested that he be kept at Farview for six months, then re-evaluated. A physician replied that treatment would be a long-term proposition in any event and that it might be easier if the charges were disposed of first. He hesitated to act on any assumption that the patient's condition would improve by the end of six months. Discussion continued, and it was the consensus of the staff that the patient was on the verge of a psychotic explosion and the stress of trial might be too great for him. It is not uncommon for the staff to decide that a patient is competent to stand trial in the legal sense yet unable to stand the stress of trial. ${ }^{152}$

Independent psychiatrists who challenge the staff evaluation by examining patients infrequently disagree with the opinion of the Farview staff. If there is disagreement, Farview suggests to the patient that he take the matter to court for a hearing. ${ }^{153}$ Frequently a judge will be unwilling to accept the view that a patient may be competent to stand trial, yet still be seriously mentally ill. ${ }^{154}$

Another problem frequently encountered is that due to court delay, a patient returned to Philadelphia to stand trial may be detained among the general Philadelphia prison population for a long period of time. Since the weakened or defective ego of a mentally ill patient lacks flexibility or adaptability, any change in his environment will cause stress and anxiety in the patient. His anxiety is heightened when the new environment is more hostile than the milieu found in the mental hospital. When this is accompanied by the mounting anxiety experienced by the patient as the date of his trial approaches, the resulting stress may be too much for him. ${ }^{155}$ The Public Defender

152 Interview with Dr. Bernard J. Willis, supra note 37.

153 Interview with Dr. John Moran, supra note 2.

154 Interviews with Dr. John Moran, supra note 2, Dr. Bernard J. Willis, supra note 37, \& Mr. Isaac Pepp, supra note 151.

155 Interviews with Drs. Edward B. Guy, C. Fred Herring, \& Bernard J. Willis, supra note 37. 
Association of Philadelphia has instituted a program which alleviates many of these problems. If, during the Public Defender's visits to Farview, he notices any indication in the files that any patient represented by the Defender Association has improved, he requests a formal evaluation of competency to stand trial. If the resulting "staff" discloses that the patient is competent, his case is docketed on the trial list. The Public Defender then consults the District Attorney to insure that he is ready to go to trial. The Defender also alerts a psychiatrist at the Maximum Security Diagnostic and Classification Center at Holmesburg that a patient from Farview will be arriving for trial and reserves a room in the psychiatric ward. He also requests the doctor to notify him personally upon the patient's return to Philadelphia. Only after all the requisite preparations are made does the Defender request the Farview staff to transfer the patient to Philadelphia. ${ }^{156}$ If such a procedure were institutionalized, most of the problems in returning the prisoner for trial would be eliminated.

Another obstacle toward having patients considered competent to stand trial is the de facto policy which appears to exist at Farview under which a mentally ill patient is returned to trial unless he appears to be unable to cope with the stress of trial. ${ }^{157}$ The doctors are concerned about both the dangerousness of a patient and the probability that if he is tried and sentenced to jail, he may receive no treatment. Still, a number of cases have been sent to Philadelphia courts for trial, wherein the defendant was mentally ill and in need of hospitalization yet he met the common law standard of competency. In one case, ${ }^{158}$ a patient who was returned to court for trial was a paranoid schizophrenic with organic brain damage. His condition was incurable by today's medical knowledge and techniques. The defendant was extremely dangerous and, in the opinion of the Farview staff, should not be allowed on the street. He stood accused of several counts of murder and several more of burglary. The Farview staff submitted three petitions to the court: one certifying the patient was competent to stand trial, the second a pre-sentence report recommending strongly that the defendant be sentenced to Farview, and the third a petition for civil commitment to Farview in case the defendant was acquitted. The disposition of this case solves the problems presented when the treatment is hindered by pending charges, guarantees the defendant's right to a speedy public trial, and is administratively efficient.

A study of the disposition of cases returned to court from Farview which was conducted in $1960^{159}$ shows a high percentage of patients freed by the court:

150 Interview with Mr. Isaac Pepp, supra note 151.

157 Text accompanying note 152 supra.

158 Survey, supra note 55.

159 Note, Hospitalization of Mentally Ill Criminals, supra note 1, at 103; cf. Vann, supra note 36 , at 32 ; Note, Incompetency to Stand Trial, supra note 7 , at 460 \& n.3. 
TABLE II

\begin{tabular}{|c|c|c|c|c|c|c|c|}
\hline Disposition & $\begin{array}{c}\text { All } \\
\text { Cases } \\
(N=146) \\
\end{array}$ & $\begin{array}{c}\text { Homi- } \\
\text { cide } \\
(N=16)\end{array}$ & $\begin{array}{c}\text { Sex } \\
\text { Crimes } \\
(N=39)\end{array}$ & $\begin{array}{c}\text { Assault } \\
\mathcal{E} \\
\text { Battery } \\
(N=23) \\
\end{array}$ & $\begin{array}{c}\text { Burglary } \\
\text { etc. } \\
(N=37)\end{array}$ & $\begin{array}{c}\text { Arson } \\
(N=13)\end{array}$ & $\begin{array}{c}\text { Other } \\
\text { Offentses } \\
(N=18) \\
\end{array}$ \\
\hline \multirow{4}{*}{$\begin{array}{l}\text { No Indictment } \\
\text { Nolle Prosequi } \\
\text { Acquittal } \\
\text { Probation } \\
\text { Suspended } \\
\text { Sentence }\end{array}$} & $1.4 \%$ & & $2.6 \%$ & & & $7.7 \%$ & \\
\hline & $\begin{array}{r}23.3 \% \\
4.8 \%\end{array}$ & $\begin{array}{l}37.5 \% \\
18.8 \%\end{array}$ & $\begin{array}{r}12.8 \% \\
2.6 \%\end{array}$ & $\begin{array}{r}34.8 \% \\
4.3 \%\end{array}$ & $18.9 \%$ & $23.1 \%$ & $\begin{array}{l}27.8 \% \\
11.1 \%\end{array}$ \\
\hline & $32.2 \%$ & $18.8 \%$ & $48.7 \%$ & $21.7 \%$ & $27.0 \%$ & $61.5 \%$ & $11.1 \%$ \\
\hline & $15.1 \%$ & - & $7.7 \%$ & $26.1 \%$ & $29.7 \%$ & $\longrightarrow$ & $11.1 \%$ \\
\hline \multirow{3}{*}{$\begin{array}{l}\text { Total Freed } \\
\text { Sentenced to } \\
\text { Prison A } \\
\text { Committed } \\
\text { to Another } \\
\text { Hospital }\end{array}$} & $76.7 \%$ & $75.0 \%$ & $74.5 \%$ & $87.0 \%$ & $75.7 \%$ & $92.3 \%$ & $61.1 \%$ \\
\hline & $20.6 \%$ & $18.8 \%$ & $23.1 \%$ & $13.0 \%$ & $24.3 \%$ & $7.7 \%$ & $27.8 \%$ \\
\hline & $2.7 \%$ & $6.4 \%$ & $2.6 \%$ & - & {[} & $\longrightarrow$ & $11.1 \%$ \\
\hline Total & $100.0 \%$ & $100.0 \%$ & $100.0 \%$ & $100.0 \%$ & $100.0 \%$ & $100.0 \%$ & $100.0 \%$ \\
\hline
\end{tabular}

A This figure represents 30 cases. In 7 of them, the face of the record, either by explicit statement of the judge or by the backdating of the sentence to the time of commitment, shows that time spent at Farview before trial was taken into account in sentencing.

A number of reasons may be given for the high rate of release: ${ }^{160}$ the judge may think that the defendant has already served enough time for his crime, or he may believe that the rehabilitative function of the criminal law has already been served, and nothing is to be gained by further incarceration. Possibly, a judge may decide that rehabilitation can best be accomplished by release under the supervision of the probation department or parole board. These reasons are appropriate and equitable if the release standard is total rehabilitation rather than competency to stand trial. However, these reasons become invalid if a person is brought to trial who still remains mentally ill, dangerous, and in need of treatment. In these cases, disposition of the charges should be followed by a treatment plan recommended by psychiatrists. Commitment back to Farview may not always be advisable, but the judge must consider the possibility that the defendant may remain mentally ill. On the other hand, it cannot be assumed that in every case where a person is returned to court as competent he is still mentally ill and commitable. Therefore, a separate evaluation of the defendant's current mental status, either by the institution of commitment procedures or by a pre-sentence evaluation, is advisable in all cases in which a defendant was found to be incompetent at one point before trial.

Finally, should the defendant be convicted and sentenced, he is entitled to credit for the time accumulated since his original commit-

160 See Vann, supra note 36 , at 31-33; Note, Hospitalization of Mentally Ill Criminals, silpra note 1 , at 104. 
ment to Farview. In Commonwealth v. Jones, ${ }^{161}$ the lower court denied the defendant credit for the time he had spent at Embreeville State Hospital, where he had been committed before he entered a plea of guilty. The court reached this result by drawing a negative implication from the fact that section 348 of the Mental Health Act of $1951{ }^{162}$ and section 411 (c) (1) of the Mental Health \& Mental Retardation Act of $1966^{163}$ expressly grant credit for time served at Farview after the patient has been sentenced. The superior court reversed and granted credit to the defendant for the time he spent in the hospital. The Jones court noted that the Pennsylvania statute which grants credit for time spent in custody before trial provides:

Any person who has been convicted of an offense . . . and sentenced to a term of imprisonment shall be given credit toward the service of his sentence for any days spent in custody on this offense prior to the imposition of his sentence....104

The court construed the words "in custody" to include detention in a mental hospital and thus was able to extend the statute to Jones himself. 165

\section{The Untreatable Patient and the Patient Requiring Long-Terim Treatment}

The thorniest problem in the area of competency to stand trial is that of the prisoner who is untreatable or who will require long-term treatment before attaining competency. A great many competency cases involve this exact situation. If the patient is untreatable, the justification for his detention-to render him competent to stand trial-cannot exist since he can never be rendered-competent. ${ }^{160}$ Pending charges hamper the patient's ability to face reality and gain insight into the nature of his problem. They also restrict the flexibility and number of treatment plans available to the attending psychiatrist. ${ }^{167}$

161211 Pa. Super. 366, 236 A.2d 834 (1967); accord, Commonwealth ex rel. Spanos v. Keenan, 102 Pitts. Legal J. 159 (Allegheny County Ct.), aff'd, $176 \mathrm{~Pa}$. Super. 245, 107 A.2d 593 (1954) ; Commonwealth v. Wright, 97 Pitts. Legal J. 301 (Allegheny County Ct. 1948).

162 No. 429, [1963] Pa. Laws 896, amending No. 581, [1952] Pa. Laws 2067 (repealed effective July 1, 1969).

103 Pa. Stat. Ann. tit. 50, $\S 4411$ (c) (1) (Supp. 1969).

164 Pa. Stat. ANN. tit. 19, $\$ 898$ (1964). This provision applies to sentences imposed prior to the date of enactment. Commonwealth v. Snyder, $427 \mathrm{~Pa} .83,103$, 233 A.2d 530, 541 (1967), cert. denied, 390 U.S. 983 (1968).

165 Accord, Commonwealth v. Martin, 213 Pa. Super. 754, 247 A.2d 664 (1968). 168 Cf. United States v. Klein, 325 F.2d 283 (2d Cir. 1963) ; Miller v. Overholser, 206 F.2d 415 (D.C. Cir. 1953).

167 See note 37 stpra \& accompanying text. 
Further, continued incarceration represents an indeterminate sentence which may run far in excess of the sentence prescribed for the crime with which the patient is charged. The fear that a supposedly humane commitment procedure might lead to the indefinite and lengthy incarceration of an allegedly untreatable defendant who would otherwise be subject to a short, fixed penal sentence was a factor in the recent Supreme Court decision of Powell v. Texas. ${ }^{168}$ The Court held that it was not cruel and unusual punishment to subject a chronic alcoholic to criminal sanctions. It was decided that he was being punished not for his status, but for being drunk in public on a particular occasion. ${ }^{160}$ In a plurality opinion, Mr. Justice Marshall stated:

Thus we run the grave risk that nothing will be accomplished beyond the hanging of a new sign-reading "hospital"-over one wing of the jailhouse.

One virtue of the criminal process is, at least, that the duration of penal incarceration typically has some outside statutory limit . . . . "Therapeutic civil commitment" lacks this feature; one is typically committed until one is "cured." Thus, to do otherwise than affirm might subject indigent alcoholics to the risk that they may be locked up for an indefinite period of time under the same conditions as before, with no more hope than before of receiving effective treatment and no prospect of periodic "freedom." 170

This reasoning applies equally to an incompetency commitment to Farview of an untreatable prisoner in lieu of possible conviction and imprisonment. The individual who is committed as incompetent with criminal charges hanging, like the sword of Damocles, over his head and who will not respond to other than long-term treatment may never be restored to competence due to the antitherapeutic effects of the charges. $^{171}$ Yet, he cannot be brought to trial without violating his right to a fair trial. ${ }^{172}$ At first glance it seems that the interests of the criminal law in trying the alleged offender and of the state's police power in restoring the defendant to mental health are irreconcilable in the case of the untreatable incompetent and the incompetent requiring long-term treatment. Yet this conflict is readily resolved when the purposes of the two conflicting powers are examined.

168392 U.S. 514 (1968).

${ }^{169} \mathrm{Id}$. at 532. But see Easter v. District of Columbia, 361 F.2d 50 (D.C. Cir. 1966), where the statute authorized the courts to take judicial notice "that a chronic alcoholic is a sick person." Id. at 51 .

170392 U.S. at 529 (footnotes omitted).

171 Note 37 supra \& accompanying text.

172 Pate v. Robinson, 383 U.S. 375, 378, 385 (1966). 
The interest of the criminal law in committing an incompetent is to restore him to competence in order that he may face the charges brought against him. ${ }^{173}$ However, once the period of commitment exceeds the statutory maximum period of imprisonment, the essential purpose of the commitment for incompetency has been frustrated; the state, even if it succeeds in convicting the defendant, cannot imprison him if he is allowed credit for the time he spent in the hospital. ${ }^{174}$ At this point, the state's interest in curing the patient should take precedence, and the criminal charges should be dropped. This would allow more effective treatment in hospitals which have less of a detrimental, penal atmosphere than Farview. Under sections $410-12$ of the Act of 1966, ${ }^{175}$ commitment of a person convicted of a crime ceases when his maximum sentence expires, but he may be recommitted under civil proceedings. Similar protection should be extended to one committed as incompetent to stand trial in order to offset the harmful effects on treatment caused by pending criminal charges.

The continued retention beyond the maximum sentence of the untreatable patient or patient requiring long-term treatment under a section 407 or section $408^{176}$ "competency" commitment, rather than a civil commitment, is a class discrimination which has no rational justification. Certainly continued incarceration beyond the maximum which criminal sanctions would allow is a discrimination vis-à-vis persons convicted of crimes who are released from detention upon expiration of the maximum sentence. ${ }^{177}$

The disposition of those cases in which a patient is untreatable or will require long-term treatment may be much more effectively accomplished on the administrative level than on a case-by-case basis. In this area, the prosecutorial nolle prosequi is of crucial importance. Yet there does not appear to be a standard administrative procedure in the office of the Philadelphia District Attorney; rather, cases are disposed of on an ad hoc basis as the possibility of a nolle prosequi is raised by the Farview staff, the Court Clinic, or someone else outside the office of the district attorney. This lack of initiative by the district attorney's office is partly responsible for the fact that as many as thirty-two per cent of the persons from Philadelphia currently committed to Farview

173 See note 121 supra \& accompanying text.

174 Commonwealth v. Jones, 211 Pa. Super. 366, 236 A.2d 834 (1967); see Greenwood v. United States, 350 U.S. 366 (1956), where the Supreme Court authorized continued commitment for incompetency in the face of unlikelihood of recovery by the patient so long as the "federal authority to prosecute" had not "been irretrievably frustrated"; id. at 375; Sturdevant v. Settle, 192 F. Supp. 534 (W.D. Mo. 1961), where the court, quoting Greenwood with approval, held that since the petitioner had been committed for a period in excess of the statutory maximum sentence, the "federal authority to prosecute has now been irretrievably frustrated.' [citation omitted]"; id. at 542. See also Foote, supra note 121, at 835-41. (1969).

175 Pa. Stat. ANn. tit. 50, §§4410-12 (Supp. 1969). See 18 U.S.C.A. $\$ 4243$

176 Pa. Stat. ANn. tit. 50, $\$ 4407, \S 4408$ (Supp. 1969).

177 Id. $\S \S 4410-12$. 
as incompetent to stand trial have been incarcerated longer than they would have been had they received maximum sentences for their alleged crimes. ${ }^{178}$ In such a case the charges against the patient should be dismissed automatically. The existence of the charges hampers treatment; and even if treatment is not possible, dropping the charges would permit transfer of the patient to a more pleasant institution or one nearer his family, if and when the Farview staff determines that this would be advisable. Civil recommitment to Farview would provide security in the case of a dangerous patient, yet because the commitment is now civil the hospital would have a freer hand in offering the patient meaningful treatment. ${ }^{179}$

\section{CONCLUSION}

The appropriate governmental officials in Pennsylvania must begin to make objective reassessment of commitment procedures. The state legislature should evaluate its recent enactment with knowledge of the stark reality of Farview, rather than the illusion of rehabilitative therapy that the hospital is supposed to offer. Furthermore, the state courts should consider seriously the real nature of the institution to which they commit sick persons. To view that institution as anything less than penal and antitherapeutic is egregious error.

These same officials must also make an even more fundamental reform of the state's entire rehabilitation apparatus. Farview is a symbol of public neglect, and an eyesore to our Constitutional heritage. It is a situation in desperate need of correction-and that relief must come quickly.

178 See text \& table accompanying notes 8-10 sipra.

179 See note 37 supra. 